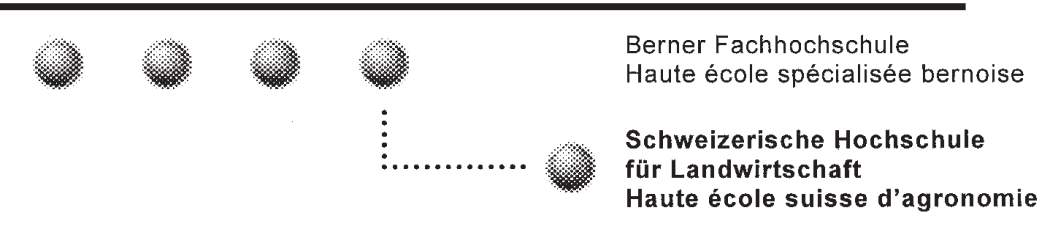

\title{
University of Applied Sciences, Bern / Swiss College of Agriculture, Zollikofen - Food Technology Specialising in Dairy Processing
}

\author{
Walter Bisig*
}

\begin{abstract}
The University of Applied Sciences Bern offers at the Swiss College of Agriculture Zollikofen internationally recognized modern modular studies in dairy and food processing technology. Courses in dairy business and management are included and prepare for challenging positions on the executive level in the dairy and food industry. In applied research and development, projects are carried out in collaboration with the dairy industry and other partners such as the Swiss Dairy Research Station or the Swiss Federal Institute of Technology (ETH). Post-formation courses allow professionals to keep up to date with evolving knowledge.
\end{abstract}

Keywords: Applied dairy research · Dairy processing · Food technology · Modular study · Post-formation

${ }^{*}$ Correspondence: Dr. W. Bisig Swiss College of Agriculture

Dairy Processing Technology Department Länggasse 85

$\mathrm{CH}-3052$ Zollikofen

Tel.: +4131910 2111

Fax: +41319102299

E-Mail:office@shl.bfh.ch

www.shl.bfh.ch

\section{Introduction}

The Swiss College of Agriculture (SCA) is part of the University of Applied Sciences of Bern. It is the only university of applied science in Switzerland offering courses in food technology and engineering specialising in dairy processing and agricultural science specialising in plant production, animal production, agricultural economics, and international agriculture.

\section{Study Programme}

The studies in dairy processing at the SCA prepare the students for attractive jobs in the dairy processing industry and give them a high level of competence in food and dairy technology, dairy business, and management. Thanks to this and their practical experience the graduates are offered challenging positions on the executive level in the dairy industry and in the food industry generally.
As one of the first Colleges of the Swiss Universities of Applied Science, SCA offers a modular timetable and applies the European Credit Transfer System. This offers the students the opportunity to spend an exchange semester in one of our partner colleges in Britain, France or Germany with full mutual acceptance of the acquired credits. The modular timetable allows personally adapted studies, with the number of optional modules increasing as the study programme progresses.

The study programme at the SCA lasts three years. The first and part of the second year focus on general skills such as communication, mathematics, information technology, natural science, economics, foreign languages, and project management.

At the heart of the specialist training from the first to the third year is the study of scientific, technical, economic, and ecological interconnections within food processing and especially dairy processing. In case studies and small-scale projects stu- 


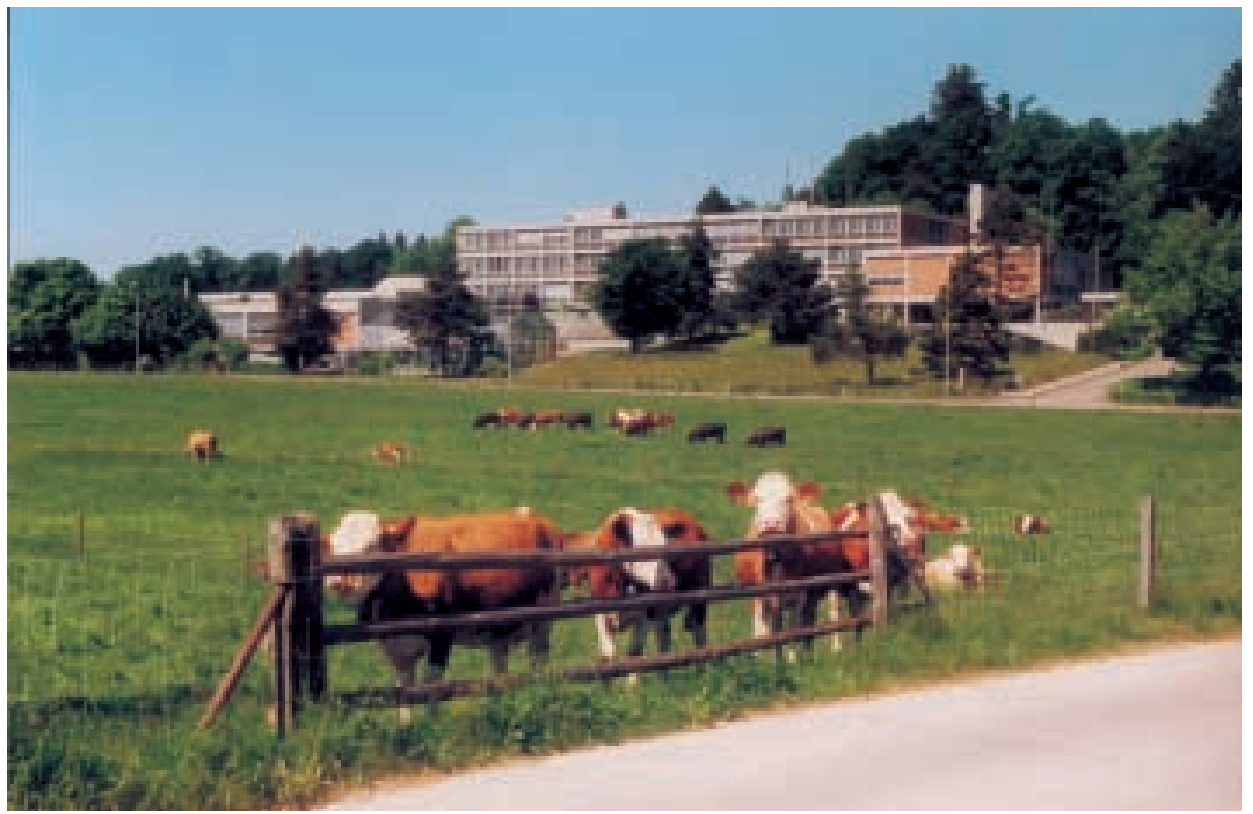

Fig. 1. Swiss College of Agriculture

dents acquire the skills to solve real-life problems.

In addition to the compulsory modules students have a wide choice of in-depth modules for their personalised study programme. For instance, a student can choose to specialise in Business Management, Teaching and Consulting or Information Technology.

The students complete their studies with a diploma project. During three and a half months a project is planned, carried out, analysed, and presented in a written report, with a poster and an oral presentation. These projects are often carried out in collaboration with our partners - the Swiss Dairy Research Station, the dairy industry or associations within the dairy and cheese business.

\section{Applied Research and Development}

In applied research and development, the SCA focuses on its strengths such as the cross-linking with the college's other fields of activity in Animal Production or International Agriculture and on its network with the Swiss Dairy Research Station and the dairy industry. One example is the study of the influence of cattle feed on the composition and properties of milk and milk products such as cheese or butter. Another example is, in collaboration with the department of International Agriculture and a program of the United Nations, a project unit in Central America to develop their dairy industry . A project in collaboration with the Swiss Dairy Research Station focuses on the functional properties of milk

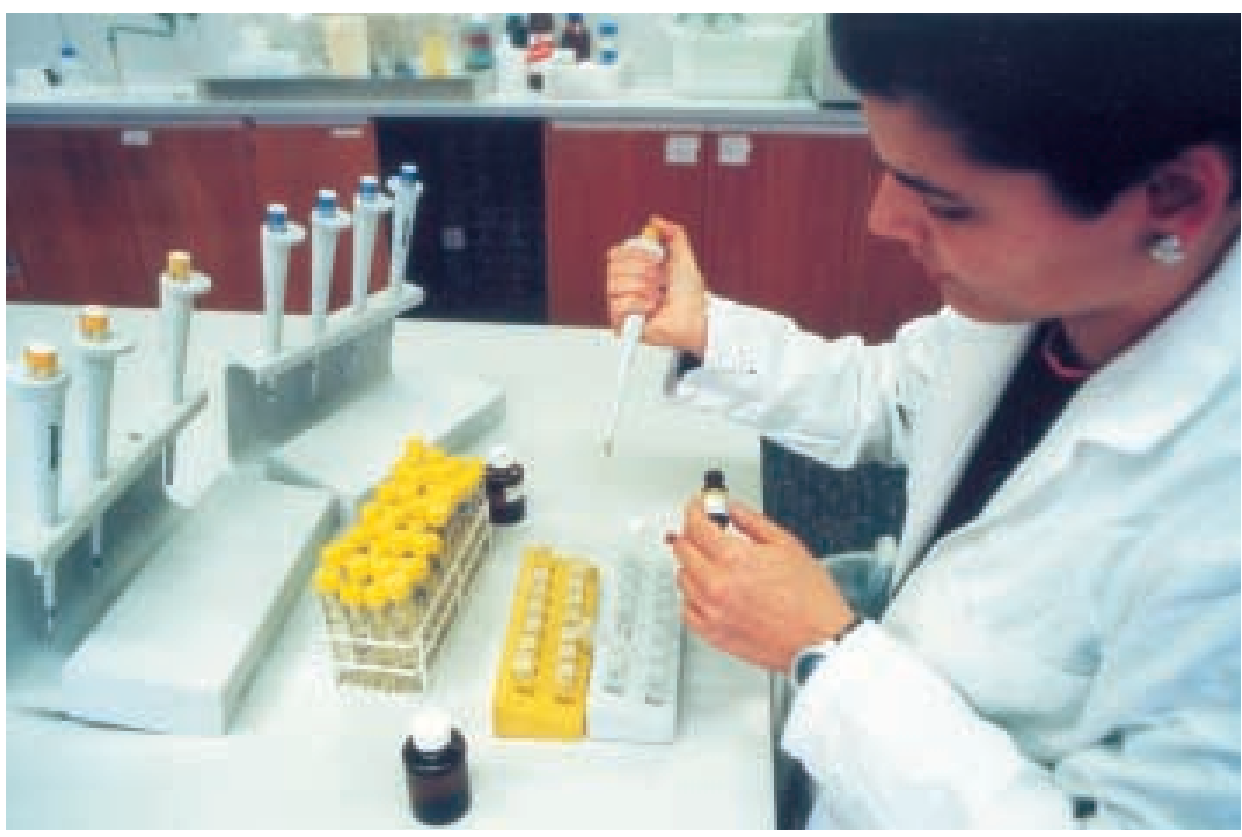

Fig. 2. Swiss College of Agriculture, Research Laboratories

proteins. The aim is to provide tailor-made natural ingredients for the food industry, which is particularly interested in "clean labelling' - labels with as few E-numbers as possible. In co-financed projects of the Swiss dairy industry and the funds of the Commission of Technology and Innovation (KTI) projects in the fields of innovative healthy dairy products and cheese are carried out.

\section{Post-formation}

In post-formation the SCA offers the possibility to follow individual or groups of modules of the food and dairy processing technology studies. With the modular timetable this is a unique opportunity and offers many synergies. A post-graduate course for dairy processing technology is offered for graduates of the Swiss Federal Institute of Technology and universities of applied science. Specific courses for postformation are organised, sometimes inhouse for industry and sometimes open to the public. For instance, a public course in sensory analysis of food is offered in summer 2002 in addition to different public seminars in management and marketing.

Received: April 23, 2002 